\title{
Trends in Consultant Appointments in Mental Handicap
}

\author{
Thomas L. Pilkington, Honorary Lecturer, Department of Psychiatry, University of Leeds
}

The DHSS/College recommended establishment for consultant posts in the psychiatry of mental handicap is one whole-time equivalent per 200,000 population. ${ }^{1}$ In 1982 the theoretical average in the English* regions was 1:321,000, varying between 1:153,000 (South West Thames) and 1:620,000 (North West). There were, however, 41 vacant posts, 19 of which were occupied by locums, ${ }^{2}$ so the actual substantive average was 1:612,000. By 1983 the number of vacant posts had risen to 49 and the substantive consultant/ population ratios varied between 1:202,000 (South Western) and 1:2,170,000 (North Western). ${ }^{3}$

Since then the situation is said to have improved and in March 1986 an up-dating survey was carried out with the help of the College's regional representatives. The findings are shown in the Table and they confirmed that the number of funded posts had risen from 150 to 203 , of which only 39 had at that time failed to attract substantive appointees, thus reducing the actual consultant/population ratio to 1:285,000.

When figures for the individual regions are compared, however, the overall gap between the regions in the "better half (all below 1:300,000) is only 74,000, in contrast to a spread of 227,000 in the less favoured half. The distribution of consultants thus remains markedly uneven and the gaps between nominal and actual appointments continue to be larger in those regions over 1:300,000. Only four regions (SW Thames, South Western, East Anglia and Oxford) meet the College's criteria.

Although there is a broad north/south polarisation in favour of the south, there are exceptions, SE Thames and Wessex being on the 'wrong' side, for example, with Merseyside performing quite well, Trent and Northern about average. As the medical chairs in this specialty have been established in the comparatively well-provided areas they are not likely to have an immediate impact on the distribution. It may be significant however that the 'Wessex initiative' and the 'Sheffield experiment' were associated with the most marked regional gains between 1983 and 1986, when their populations per consultant were reduced by $400-450,000$, although they both remain significantly above the recommended norm.

-The situations in Scotland and Wales may be significantly affected by the greater emphasis on NHS-funded services in Scotland and by the implications of the All-Wales Strategy for mental handicap services.
The College recognises three types of consultant posts: whole-time, joint appointments with a balanced number of sessions, and special interest posts, for all of which senior registrar training with further experience in mental handicap is required. ${ }^{1,4}$ In some districts with chronic shortages, however, specialist consultant sessions have, in effect, been dispensed with, perhaps encouraged by local interpretations of 'normalisation' and by the anti-psychiatry movement. The outcome of this drift may also be influenced by the development of the independent community nursing services in these areas and by the impact of the current nurse-training syllabus, which requires little knowledge of psychiatry. Although the College proposes a specialised psychiatric service for the mentally handicapped, ${ }^{5}$ some consultants, depending upon their previous experience, may hold differing views of their own roles in this field.

These trends should be seen in the perspective of other local inequalities in the health services, and on the background of shifts in national priorities, but when a service falls below a critical level in quantity and quality of consultant influence it may reach a point of no return in that respect unless a new prescription can be formulated. When received advice cannot be put into practice the effects of local solutions may erode the service as a whole. This study suggests the need for special initiatives in these areas to restore the balance and to promote a more equitable quality of service.

\section{ACKNOWLEDGEMENT}

I am grateful to the College's regional representatives in the English regions for kindly sending me details of the local consultant situations.

\section{ReFERENCES}

'Royal College of Psychiatrists (1985) Guidelines for regional advisers on consultant posts in mental handicap. Bulletin of the Royal College of Psychiatrists, 9, 207-208.

2 - (1983) Mental handicap services - the future. Bulletin of the Royal College of Psychiatrists, 7, 131-134.

${ }^{3}$ Pilkington, T. L. (1983) Specialised needs of the retarded: epidemiological surveys. Proceedings, VIIth Congress, World Psychiatric Association, 5, 211-216.

"Royal College of Psychatrists (1986) Criteria for consultant posts in psychiatry. Bulletin of the Royal College of Psychiatrists, 10, 201-202.

s_ _ (1986) Psychiatric services for mentally handicapped adults and young people. Bulletin of the Royal College of Psychiatrists, $10,321-322$. 
TABLE

Comparison between consultant appointments in mental handicap between 1983 and 1986

\begin{tabular}{|c|c|c|c|c|c|c|c|c|c|}
\hline \multirow[t]{2}{*}{ Region } & \multirow[t]{2}{*}{ Population } & \multirow[t]{2}{*}{ Estab. } & \multirow[t]{2}{*}{ Vacant } & \multicolumn{2}{|c|}{ Population/Cons. } & \multirow[t]{2}{*}{ Estab. } & \multirow[t]{2}{*}{ Vacant } & \multicolumn{2}{|c|}{ Population/Cons. } \\
\hline & & & & Nominal & Substant. & & & Nominal & Substant. \\
\hline $\begin{array}{l}\text { South West } \\
\text { Thames }\end{array}$ & $2,906,000$ & 19 & 5 & 153,000 & 208,000 & 22 & 5 & 132,000 & 182,000 \\
\hline South Western & $3,029,000$ & 18 & 3 & 168,000 & 202,000 & 17.5 & 0 & 173,000 & 173,000 \\
\hline East Anglia & $1,863,000$ & 11 & 3 & 169,000 & 233,000 & 11 & 2 & 169,000 & 207,000 \\
\hline West Midland & $5,161,000$ & 17 & 6 & 304,000 & 469,000 & 21 & 1 & 245,000 & 258,000 \\
\hline Merseyside & $2,458,000$ & 8 & 2 & 307,000 & 410,000 & 10.5 & 1 & 234,000 & 259,000 \\
\hline Oxford & $2,340,000$ & 7 & 2 & 334,000 & 468,000 & 14 & 3 & 167,000 & 213,000 \\
\hline $\begin{array}{c}\text { North West } \\
\text { Thames }\end{array}$ & $3,460,000$ & 10 & $\mathbf{0}$ & 346,000 & 346,000 & 15 & 2 & 231,000 & 266,000 \\
\hline Trent & $4,517,000$ & 13 & 7 & 347,000 & 752,000 & 20 & 6 & 226,000 & 323,000 \\
\hline $\begin{array}{l}\text { North East } \\
\text { Thames }\end{array}$ & $3,772,000$ & 10 & 4 & 377,000 & 629,000 & 16 & 1 & 236,000 & 251,000 \\
\hline Northern & $3,087,000$ & 8 & 3 & 385,000 & 617,000 & 11 & 1 & 281,000 & 309,000 \\
\hline $\begin{array}{c}\text { South East } \\
\text { Thames }\end{array}$ & $3,544,000$ & 9 & 1 & 394,000 & 443,000 & 13 & 5 & 273,000 & 443,000 \\
\hline Wessex & $2,744,000$ & 6 & 3 & 457,000 & 915,000 & 6 & 0 & 457,000 & 457,000 \\
\hline Yorkshire & $3,577,000$ & 7 & 5 & 511,000 & 715,000 & 12.5 & 5 & 286,000 & 477,000 \\
\hline North West & $4,339,000$ & 7 & 5 & 620,000 & $2,170,000$ & 13.5 & 5 & 321,000 & 510,000 \\
\hline TOTALS & $46,797,000$ & 150 & 49 & 312,000 & 463,000 & 203 & 38 & 231,000 & 284,000 \\
\hline
\end{tabular}

\title{
The Role of the Consultant Psychiatrist in Mental Handicap
}

\section{A Personal View}

\author{
Caroline Marriott, Senior Registrar, Stradreagh Hospital, Londonderry, Northern Ireland
}

Since taking the decision to pursue a career in mental handicap, I have been increasingly aware of the debate surrounding the role of the consultant psychiatrist in this field. Nowhere else in medicine does there seem to be such uncertainty about the continued need for an already established specialty. I believe that one of the major reasons for the continued difficulty in attracting trainees into mental handicap is precisely this uncertainty about its future, which is in no way ameliorated by the College's view that a full time specialist appointment in the psychiatry of mental handicap is not superior to a joint appointment either with adult or child psychiatry. ${ }^{1}$

It seems clear that the case for the core involvement of the specialist consultant psychiatrist in the planning and provision of services for the mentally handicapped (in addition to providing a psychiatric service for them) has not been made. Are we opting out? I suspect that the Select Committee for Social Services believes we are, and it appears they believe we should not. ${ }^{2}$

I believe that there is a real need for full-time, properly trained specialists in mental handicap, and that their role should be a broadly based one, set in a holistic view of the needs of the mentally handicapped person and his family, and in encouraging mental health rather than treating psychiatric disorder after it has arisen.

The principles on which the role of the consultant psychiatrist in mental handicap should be based have been well stated by DHSS (NI) in $1978 .{ }^{3}$ Broadly, they are as follows:

(1) He should be concerned with the initial and on-going assessment of mental handicap, and the provision of a psychiatric service for affected individuals.

(2) He must be concerned with the prevention and assessment of emotional disturbance in the handicapped person and/or his family.

(3) He must give medical leadership within the hospital part of the service, and in the management and support of the handicapped and their families.

(4) He should act effectively in co-ordinated multidisciplinary teams which exist for the benefit of the handicapped for whose care he (in liaison with the general practitioner) has clinical responsibility. 